\title{
KAJIAN LINGKUNGAN PENGENDAPAN BATUBARA BERDASARKAN ANALISIS PETROGRAFI ORGANIK PADA FORMASI MUARA ENIM, CEKUNGAN SUMATERA SELATAN
}

\author{
Coal Deposition Environment Study Based on Organic Petrography \\ Analysis of Muara Enim Formation, South Sumatera Basin
}

\author{
AMELIA P. MONITA ${ }^{1 *}$, NOOR C. D. ARYANTO ${ }^{2 * *}$ dan YUNUS ASHARI ${ }^{1 * *}$ \\ ${ }^{1}$ Program Studi Teknik Pertambangan, Fakultas Teknik, Universitas Islam Bandung \\ Jl. Tamansari No.1 Bandung 40116 \\ Telp. (022) 4203368 \\ e-mail : ameliapuspam16@gmail.com \\ 2 Pusat Penelitian dan Pengembangan Geologi Kelautan (PPPGL) Bandung \\ J. Dr. Djunjunan No.236 Bandung 40174 \\ Telp. (022) 6032020 \\ * Kontributor Utama, ** Kontributor Anggota
}

\begin{abstract}
ABSTRAK
Karakteristik batubara merupakan salah satu aspek pertimbangan dalam mengembangkan suatu industri pertambangan batubara. Karakteristik batubara seperti peringkat, kualitas dan tipe dikontrol dan dipengaruhi oleh lingkungan tempat diendapkannya batubara tersebut. Dengan mengetahui lingkungan pengendapan batubara, secara tidak langsung dapat diperkirakan pula karakteristik batubara tersebut. Percontoh batubara yang diuji berasal dari lapisan batubara Formasi Muara Enim Cekungan Sumatera Selatan, Kecamatan Merapi Barat, Kabupaten Lahat. Penelitian dilakukan menggunakan metode analisis petrografi organik untuk mengetahui komposisi maseral dan mineral penyusunnya serta metode analisis stratigrafi untuk mengetahui fasies batuan penyusun serta memperkuat pemikiran dalam penentuan lingkungan pengendapan batubara daerah penelitian. Interpretasi lingkungan pengendapan batubara dilakukan berdasarkan hubungan nilai tissue preservation index (TPI) dan gelification index (GI) dan hasil perbandingan model fasies yang didapat dengan model lingkungan pengendapan yang telah ada sebelumnya. Kandungan kelompok maseral huminit mendominasi batubara daerah penelitian (>50\%) diikuti dengan kelompok maseral liptinit dan inertinit. Berdasarkan analisis petrografi organik batubara, daerah penelitian memiliki rentang nilai TPI 0,88-1,61 dan GI 6,98-37,33, sehingga menunjukkan bahwa batubara daerah penelitian terendapkan di lingkungan pengendapan transitional lower delta plain dengan sublingkungan pengendapannya berupa telmatic dan limno-telmatic pada rawa gambut wet forest swamp dan fen. Lingkungan ini terpengaruh oleh transgresi air laut. Pengaruh tersebut tidak terlalu signifikan dibuktikan dengan rendahnya kandungan mineral pirit $(0,20-1,80 \%)$. Berdasarkan posisi stratigrafinya, daerah penelitian terendapkan pada lingkungan rawa. Hal ini diketahui karena adanya kontak atas dan bawah yang memperlihatkan kandungan karbonan berangsur terdiri atas batubara menjadi batulempung karbonan kaya kandungan unsur organik berupa unsur karbon. Kandungan unsur karbon ini diperlihatkan dari warna litologi hitam. Dari kandungan unsur organik tersebut, pembentukan batubara berlangsung dalam kondisi tenang, sehingga ditafsirkan diendapkan pada lingkungan rawa delta.
\end{abstract}

Kata kunci: Formasi Muara Enim, analisis petrografi organik, komposisi maseral, TPI dan Gl, lingkungan pengendapan.

\begin{abstract}
Characteristics of coal such as rank, quality, and type are controlled and influenced by the environment in which the coal is deposited. Those are the aspects that should be considered in developing a coal mining industry. By
\end{abstract}


evaluating the environment of coal deposition, the characteristics of the coal can be estimated indirectly. Samples for this study were obtained from Muara Enim Formation's coal seams of South Sumatera Basin, West Merapi District, Lahat Regency. The study was conducted using organic petrography analysis to determine the mineral and maceral composition of coals as well as stratigraphy analysis to determine the constituent rock facies and to strengthen the idea of determining the coal depositional environment in the studied area. Interpretation of coal depositional environment was carried out based on the relationship between the value of tissue preservation Index (TPI) and gelification index $(\mathrm{Gl})$ and the results of the comparison of the facies model obtained with the existing depositional environment model. The content of the huminite maceral group dominated the coal in the studied area (> 50\%), followed by the liptinite and inertinite maceral group. Based on the coal organic petrographic analysis, the coals have a range of values 0.88-1.61 and Gl 6.98-37.33, so it shows that coals in the study area were deposited in the transitional lower delta plain depositional environment with the sub-environment in the form of telmatic and limno-telmatic on wet forest swamp and fen peat swamps. This effect is not too significant, as evidenced by the low mineral content of pyrite $(0.20-1.80 \%)$. Based on its stratigraphic position, the studied area was deposited in a swampy environment. This can be seen because the presence of upper and lower contacts shows the carbon content, which gradually consists of coal into carbonan claystone which is rich in organic elements in the form of carbon elements. The content of this carbon element is shown from the black lithologic colour. From the content of these organic elements, the formation of coal took place in calm conditions, so it is interpreted as being deposited in a delta swamp environment.

Keywords: Muara Enim Formation, organic petrography analysis, maceral, TPI and GI, depositional environment

\section{PENDAHULUAN}

Secara umum, pembentukan batubara dipengaruhi oleh lingkungan pengendapannya yang mencangkup beberapa faktor, di antaranya letak geografi dan iklim, perkembangan dan pertumbuhan vegetasi, pengaruh struktur deformasi tektonik, akumulasi vegetasi, tumbuhan pembentuk batubara, topografi lingkungan pengendapan serta proses transformasi vegetasi menjadi batubara. Faktor-faktor tersebut menentukan ketebalan, kualitas, distribusi lateral dan vertikal batubara. Untuk mengetahui karakteristik batubara, biasanya dilakukan studi petrografi batubara, yaitu pendekatan dalam melihat komponen organik dan anorganik secara mikroskopis, yang menekankan pada cara pemerian dan klasifikasi batubara secara sistematis (Stach $d k k ., 1982)$. Hasil studi ini juga dapat dipakai untuk menafsirkan lingkungan pengendapan batubara.

Daerah penelitian berada pada Formasi Muara Enim, bagian barat daya Cekungan Sumatera Selatan yang termasuk ke dalam daerah administrasi Kecamatan Merapi Barat, Kabupaten Lahat, Provinsi Sumatera Selatan. Penelitian ini membahas komposisi maseral dan mineral tertentu yang terkandung pada percontoh batubara berdasarkan analisis petrografi organik dan didukung oleh data analisis stratigrafi untuk mengetahui lingkungan pengendapan batubara pada daerah penelitian.

\section{GEOLOGI}

Batubara daerah penelitian berasal dari Formasi Muara Enim yang merupakan salah satu formasi penyusun batuan di Cekungan Sumatera Selatan. Pembentukan cekungan ini diawali dengan proses sedimentasi yang diperkirakan berlangsung selama Zaman Tersier disertai dengan penurunan dasar cekungan hingga ketebalan sedimen mencapai 600 meter (IAGI Learning Centre, 2017). Siklus pengendapan cekungan ini terbagi dalam dua fase, yaitu fase transgresif dan regresif. Awalnya dimulai dengan siklus nonmarin, yaitu proses diendapkannya Formasi Lahat pada Oligosen Awal, setelah itu diikuti oleh Formasi Talang Akar yang diendapkan di atasnya secara tidak selaras. Fase transgresif terus berlangsung hingga Miosen Awal, dan berkembang Formasi Baturaja yang terdiri dari batuan karbonat yang di dalamnya terdapat serpih dan serpih gampingan yang diendapkan pada laut dalam dan berkembang di daerah platform dan tinggian. Fase transgresif maksimum diendapkan Formasi Gumai secara selaras di atas Formasi Baturaja pada Miosen Tengah.

Fase regresif terjadi pada saat diendapkannya Formasi Gumai bagian atas dan diikuti oleh pengendapan Formasi Air Benakat secara selaras yang didominasi oleh litologi batupasir pada lingkungan pantai dan delta. Pada Miosen Akhir, laut menjadi semakin dangkal, karena terdapat dataran delta dan nonmarin yang terdiri dari perselingan batupasir dan 
batulempung dengan sisipan batubara. Pada saat Miosen Akhir, terjadi pembentukan Formasi Muara Enim yang berlangsung sampai Pliosen (Bishop, 2001).

Formasi Muara Enim merupakan siklus regresif kedua sebagai pengendapan laut dangkal. Pengendapan awal terjadi di sepanjang lingkungan rawa-rawa dataran pantai, terjadi di bagian selatan Cekungan Sumatera Selatan, menghasilkan endapan batubara yang luas. Pengendapan berlanjut pada lingkungan delta plain dengan perkembangan secara lokal sekuen serpih dan batupasir yang tebal. Pada formasi ini terdapat oksida besi berupa konkresi-konkresi dan kayu terkersikkan. Batubara Formasi Muara Enim umumnya berupa lignit. Ketebalan formasi ini tipis di bagian utara dan maksimum berada di sebelah selatan dengan ketebalan 450-750 meter (Bishop, 2001). Statigrafi regional Cekungan Sumatera Selatan telah banyak digambarkan pada kolom stratigrafi oleh para peneliti, salah satunya adalah kolom stratigrafi Cekungan
Sumatera Selatan menurut Susilawati \& Ward (Susilawati and Ward, 2006) dapat dilihat pada Gambar 1.

Formasi Muara Enim bertindak sebagai pembawa batubara utama pada daerah penelitian. Berdasarkan pembagian (Mijnbouw, 1978), Formasi Muara Enim dapat dibagi menjadi empat anggota dengan urutan dari tua ke muda, yaitu M1, M2, M3, dan M4, masingmasing dibatasi oleh lapisan batubara menerus. Bila lapisan batubara menghilang atau berubah, batasnya ditentukan dari hasil perubahan batubara menjadi batulempung hitam atau coklat. Titik pengambilan percontoh berada pada anggota M3 seperti yang ditunjukkan pada peta geologi lokal daerah penelitian (Gambar 2) yang tersusun atas batupasir dan sedikit batulempung serta batulanau, mengandung beberapa lapisan tipis batubara. Batupasir dalam anggota ini dicirikan oleh kehadiran nodulnodul batubesi kalsitan yang mempunyai rongga-rongga bekas gas (Gafoer, Cobrie and Purnomo, 1986).

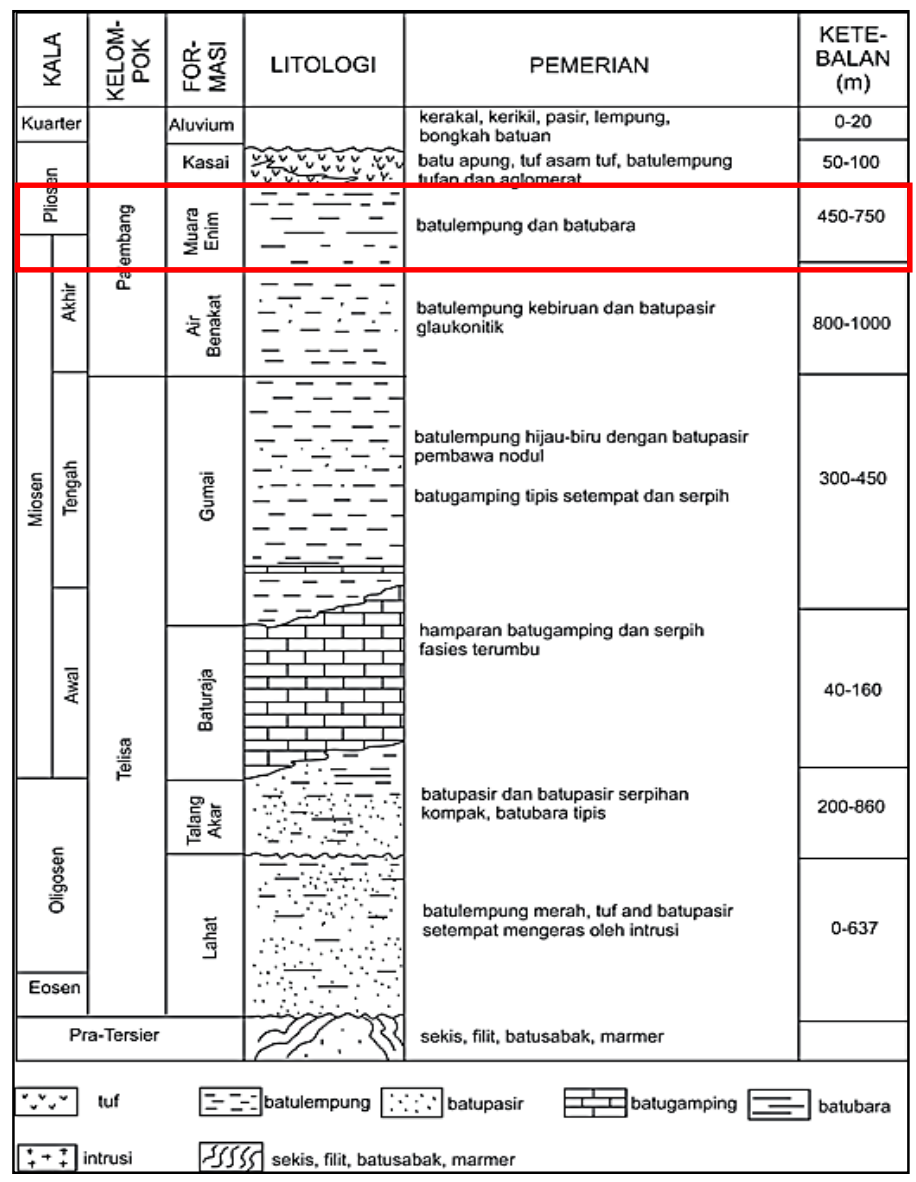

Gambar 1. Stratigrafi regional Cekungan Sumatera Selatan (Susilawati and Ward, 2006) 


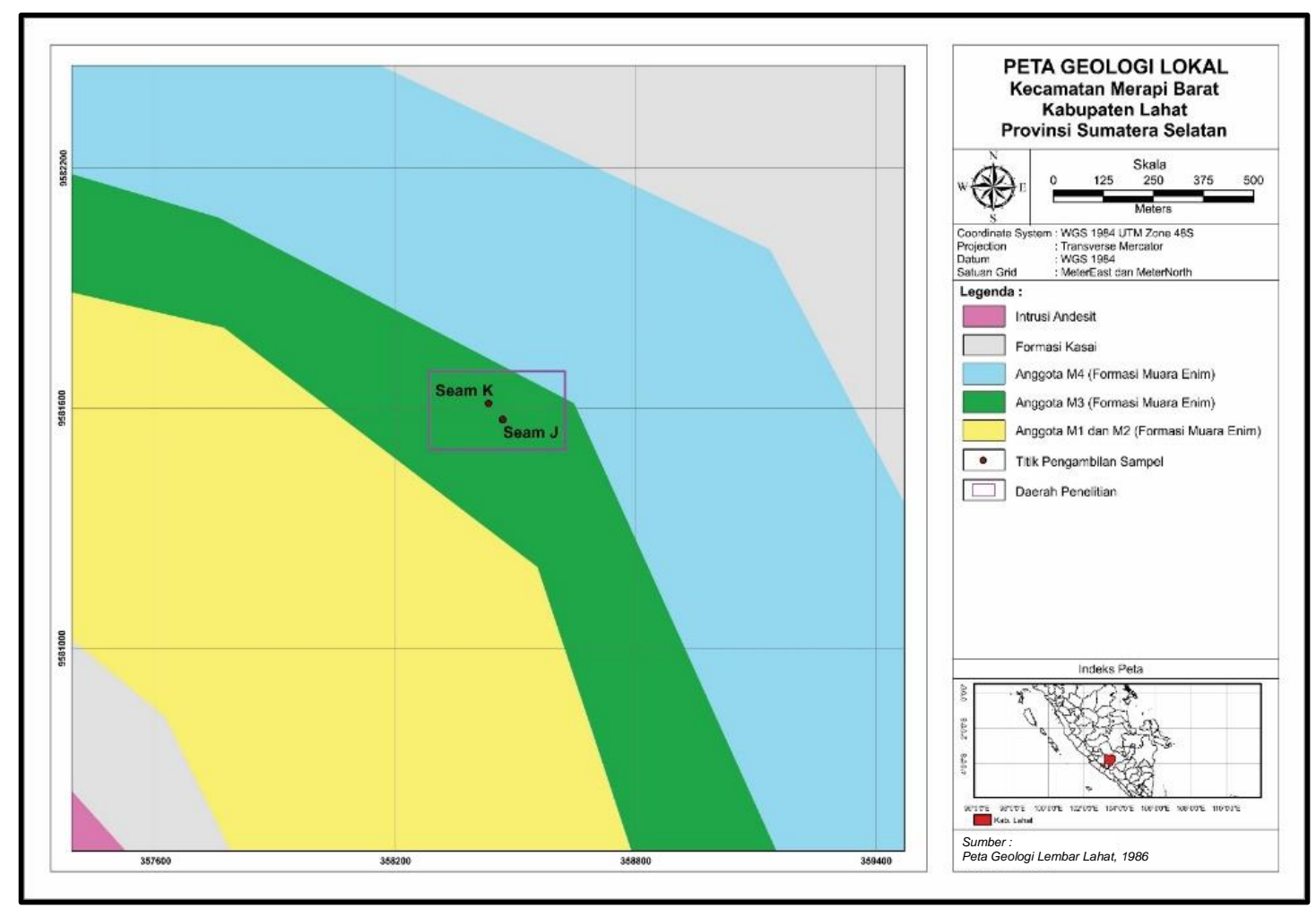

Gambar 2. Peta geologi lokal daerah penelitian (Gafoer $d k k ., 1986)$

\section{METODE}

Interpretasi lingkungan pengendapan batubara pada penelitian ini ditentukan berdasarkan nilai tissue presevation index (TPI) dan gelification index (Gl) oleh Diessel (1992) yang didapatkan dari hasil analisis petrografi organik. Analisis dilakukan berdasarkan skala laboratorium dengan meneliti 12 percontoh batubara Lapisan Batubara J dan K.

Analisis petrografi organik dilakukan untuk mengetahui komposisi maseral pada setiap percontoh sayatan poles batubara di bawah mikroskop, dan dilakukan sebanyak 500 titik pengamatan menggunakan sinar putih (reflected white light) dan sinar fluoresen (reflected fluorescent light).

Hasil studi pustaka menurut Purnama $d k k$., (2018) mengatakan bahwa batubara Formasi Muara Enim termasuk dalam batubara peringkat rendah, sehingga terminologi yang digunakan dalam mengidentifikasi maseral mengikuti acuan International Committee for Coal and Organic Petrology (ICCP, 1971).
Tabel 1. Klasifikasi maseral batubara (ICCP, 1971).

\begin{tabular}{|c|c|c|}
\hline $\begin{array}{c}\text { Grup } \\
\text { Maseral }\end{array}$ & $\begin{array}{l}\text { Subgrup } \\
\text { Maseral }\end{array}$ & Maseral \\
\hline \multirow{3}{*}{$\begin{array}{l}\text { Huminit } \\
\text { (Vitrinit) }\end{array}$} & $\begin{array}{l}\text { Humotelinit } \\
\text { (Telovitrinit) }\end{array}$ & $\begin{array}{l}\text { Tekstinit } \\
\text { Ulminit }\end{array}$ \\
\hline & $\begin{array}{l}\text { Humodetrinit } \\
\text { (Detrovitrinit) }\end{array}$ & $\begin{array}{c}\text { Atrinit } \\
\text { Densinit }\end{array}$ \\
\hline & $\begin{array}{l}\text { Humokolinit } \\
\text { (Gelovitrinit) }\end{array}$ & $\begin{array}{c}\text { Gelinit } \\
\text { Korpogelinit } \\
\text { Korpohuminit }\end{array}$ \\
\hline Liptinit & & $\begin{array}{c}\text { Sporinit } \\
\text { Kutinit } \\
\text { Resinit } \\
\text { Suberinit } \\
\text { Alginit } \\
\text { Liptodetrinit } \\
\text { Eksudatinit } \\
\text { Flourinit } \\
\end{array}$ \\
\hline \multirow[t]{3}{*}{ Inertinit } & Teloinertinit & $\begin{array}{c}\text { Fusinit } \\
\text { Semifusinit } \\
\text { Funginit } \\
\text { Sekretinit }\end{array}$ \\
\hline & Detroinertinit & $\begin{array}{c}\text { Inertodetrinit } \\
\text { Mikrinit }\end{array}$ \\
\hline & Geloinertinit & Makrinit \\
\hline
\end{tabular}


Data komposisi maseral dan mineral tertentu yang telah didapatkan selanjutnya diolah menggunakan rumus TPI (1) dan GI (2), kemudian diplot dalam diagram TPI-GI Diessel (1986).

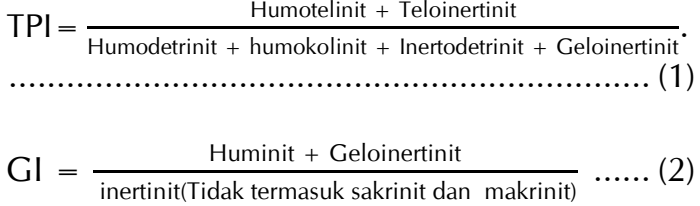

$\mathrm{GI}=\frac{\text { Huminit }+ \text { Geloinertinit }}{\text { inefinit(Tidak termasuk sakrinit dan }}$ inertinit(Tidak termasuk sakrinit dan makrinit)

Analisis stratigrafis dilakukan untuk memperkuat gagasan dalam penentuan lingkungan pengendapan batubara dengan cara membandingkan fasies model batuan yang telah ada sebelumnya dengan fasies batuan pada data stratigrafi daerah penelitian. Model pembanding yang digunakan adalah model lingkungan pengendapan menurut Horne $d k k$. (1978).

\section{HASIL DAN PEMBAHASAN}

\section{Komposisi Maseral dan Mineral Batubara}

Batubara yang terdapat pada Formasi Muara Enim secara petrografis umumnya terdiri atas kelompok maseral huminit dan liptinit. Maseral huminit terdiri atas subkelompok humodetrinit, humokolinit dan lapisan tipis humotelinit. Liptinit terdiri atas resinit, kutinit, suberinit, sporinit, liptodetrinit, fluorinit, alginit dan eksudatinit. Inertinit jarang sekali ditemukan dalam batubara Sumatera Selatan. Sekitar $50 \%$ fragmen inertinit adalah semifusinit dan funginit, sementara sisanya adalah sklerotinit, inertodetrinit, dan sedikit fusinit. Batubara Formasi Muara Enim mengandung sedikit mineral $(<5 \%)$ yang meliputi pirit dan mineral lempung. Pirit terlihat dalam bentuk butiran-butiran halus. Mineral lempung terlihat sebagai inklusi butiran halus yang tersebar hampir di semua batubara. Mineral lempung ini mengisi ronggarongga pada sel tumbuhan dan umumnya berasosiasi dengan maseral huminit (Santoso, 2015).

Dalam skala yang lebih kecil, Formasi Muara Enim di daerah penelitian menunjukkan hasil analisis petrografi organik didominasi oleh kelompok maseral huminit $(65,00-89,60 \%)$, dengan persentase rata-rata subkelompok maseral humotelinit $(41,13 \%)$, subkelompok maseral humodetrinit (31,65\%) dan subkelompok maseral humokolinit $(5,21 \%)$. Untuk kelompok maseral liptinit menunjukkan nilai yang relatif sedang, yaitu 5,20-24,00\%. Lain halnya dengan kelompok maseral inertinit, kelompok maseral ini menunjukkan nilai persentase relatif rendah dibandingkan dengan kelompok maseral lainnya, yaitu 2,40$9,20 \%$, yang terdiri dari subkelompok maseral teloinertinit $(4,95 \%)$ dan subkelompok maseral detroinertinit $(0,48 \%)$. Untuk kandungan mineral menunjukkan nilai beragam, yaitu 1,20-4,20\%, terdiri dari lempung dengan persentase rata-rata $1,56 \%$, pirit $(1,01 \%)$ dan mineral lain $(0,46 \%)$. Komposisi maseral dan mineral batubara daerah penelitian secara rinci dapat dilihat pada Tabel 2.

Tabel 2. Komposisi petrografi batubara Lapisan Batubara J dan Lapisan Batubara K

\begin{tabular}{|c|c|c|c|c|c|c|c|c|c|c|c|c|}
\hline \multirow{2}{*}{$\begin{array}{l}\text { Komposisi } \\
\text { petrografi }\end{array}$} & \multicolumn{12}{|c|}{ Percontoh batubara } \\
\hline & A1 & A2 & A3 & A4 & A5 & A6 & B1 & B2 & B3 & B4 & B5 & B6 \\
\hline \multicolumn{13}{|l|}{ Maseral (vol.\%) } \\
\hline Tekstinit & 1,80 & 4,80 & 5,00 & 3,60 & 7,00 & 3,80 & 2,40 & 2,00 & 2,80 & 0,60 & 0,00 & 1,40 \\
\hline Ulminit & 38,6 & 34,2 & 35,6 & 30,6 & 32,6 & 39,2 & 41,6 & 36,0 & 40,2 & 37,4 & 44,8 & 47,6 \\
\hline $\begin{array}{c}\text { (Total } \\
\text { Humotelinit) }\end{array}$ & 40,4 & 39,0 & 40,6 & 34,2 & 39,6 & 43,0 & 44,0 & 38,0 & 43,0 & 38,0 & 44,8 & 49,0 \\
\hline Atrinit & 32,6 & 19,0 & 19,4 & 39,0 & 17,2 & 30,4 & 26,8 & 42,6 & 31,6 & 43,2 & 36,2 & 37,8 \\
\hline Densinit & 1,00 & 0,60 & 0,40 & 0,00 & 0,00 & 0,00 & 0,60 & 0,00 & 1,00 & 0,00 & 0,00 & 0,00 \\
\hline $\begin{array}{c}\text { (Total } \\
\text { Humodetrinit) }\end{array}$ & 33,6 & 19,6 & 19,8 & 39,0 & 17,2 & 30,4 & 27,4 & 42,6 & 32,6 & 43,2 & 36,2 & 37,8 \\
\hline Gelinit & 0,60 & 0,60 & 0,40 & 0,60 & 0,20 & 0,00 & 0,20 & 0,20 & 0,20 & 0,00 & 0,40 & 0,00 \\
\hline Korpogelinit & 0,60 & 0,60 & 0,40 & 0,40 & 1,80 & 0,40 & 1,00 & 0,40 & 0,60 & 0,40 & 0,40 & 0,60 \\
\hline Korpohuminit & 3,00 & 6,00 & 5,60 & 4,00 & 6,20 & 3,40 & 3,40 & 2,60 & 4,40 & 3,80 & 7,00 & 2,20 \\
\hline $\begin{array}{c}\text { (Total } \\
\text { Humokollinit) }\end{array}$ & 4,20 & 7,20 & 6,40 & 5,00 & 8,20 & 3,80 & 4,60 & 3,20 & 5,20 & 4,20 & 7,80 & 2,80 \\
\hline Total Huminit & 78,2 & 65,8 & 66,8 & 78,2 & 65,0 & 77,2 & 76,0 & 83,8 & 80,8 & 85,4 & 88,8 & 89,6 \\
\hline
\end{tabular}




\begin{tabular}{|c|c|c|c|c|c|c|c|c|c|c|c|c|}
\hline \multirow{2}{*}{$\begin{array}{l}\text { Komposisi } \\
\text { petrografi }\end{array}$} & \multicolumn{12}{|c|}{ Percontoh batubara } \\
\hline & A1 & A2 & A3 & A4 & A5 & A6 & B1 & B2 & B3 & B4 & B5 & B6 \\
\hline Sporinit & 4,60 & 6,20 & 6,20 & 1,20 & 6,60 & 3,00 & 3,80 & 2,40 & 1,20 & 1,40 & 0,60 & 0,60 \\
\hline Kutinit & 1,80 & 5,60 & 4,80 & 3,20 & 5,40 & 2,60 & 3,20 & 1,60 & 3,20 & 3,00 & 3,20 & 1,80 \\
\hline Resinit & 4,40 & 5,40 & 5,00 & 5,20 & 4,60 & 4,20 & 3,40 & 2,40 & 3,60 & 2,00 & 1,80 & 1,60 \\
\hline Suberinit & 1,80 & 2,20 & 1,80 & 1,40 & 2,20 & 0,40 & 0,40 & 2,20 & 2,20 & 1,20 & 1,20 & 0,80 \\
\hline Alginit & 0,20 & 0,40 & 0,60 & 0,20 & 1,60 & 1,40 & 0,00 & 0,00 & 0,20 & 0,20 & 0,00 & 0,00 \\
\hline Liptodetrinit & 0,00 & 0,00 & 0,00 & 0,00 & 0,80 & 0,60 & 1,40 & 0,20 & 0,60 & 0,40 & 0,00 & 0,40 \\
\hline Eksudatinit & 0,40 & 1,60 & 1,40 & 0,20 & 2,80 & 1,40 & 1,00 & 0,60 & 0,20 & 0,40 & 0,00 & 0,00 \\
\hline Flourinit & 0,00 & 0,00 & 0,00 & 0,00 & 0,00 & 0,00 & 0,00 & 0,40 & 0,60 & 0,00 & 0,00 & 0,00 \\
\hline Total Liptinit & 13,20 & 21,4 & 19,8 & 11,40 & 24,0 & 13,6 & 13,2 & 9,80 & 11,80 & 8,60 & 6,80 & 5,20 \\
\hline Fusinit & 0,00 & 1,00 & 0,80 & 0,60 & 1,20 & 0,40 & 1,80 & 0,80 & 1,40 & 0,80 & 0,40 & 0,00 \\
\hline Semifu & 40 & 2,00 & 1,60 & 1,00 & 0,60 & 0,80 & 0,60 & 0,40 & 0,20 & 0,40 & 0,20 & 0,40 \\
\hline Funginit & 3,60 & 4,20 & 5,40 & 3,80 & 4,40 & 3,60 & 4,00 & 2,60 & 3,80 & 2,00 & 2,20 & 2,00 \\
\hline Sekretinit & 0,00 & 0,00 & 0,00 & 0,00 & 0,00 & 0,00 & 0,00 & 0,00 & 0,00 & 0,00 & 0,00 & 0,00 \\
\hline Teloinertinit & 4,00 & 7,20 & 7,80 & 5,40 & 6,20 & 4,80 & 6,40 & 3,80 & 5,40 & 3,20 & 2,80 & 2,40 \\
\hline Inertodetrinit & 0,00 & 0,80 & 1,00 & 0,00 & 0,40 & 0,00 & 0,40 & 0,00 & 0,00 & 0,00 & 0,00 & 0,00 \\
\hline Mikrinit &, 00 & 0,60 & 0,40 & 0,00 & 0,60 & 0,20 & 0,00 & 0,40 & 0,60 & 0,00 & 0,40 & 0,00 \\
\hline Detroinertinit &, 00 & 1,40 & 1,40 & 0,00 & 1,00 & 0,20 & 0,40 & 0,40 & 0,60 & 0,00 & 0,40 & 0,00 \\
\hline Makrinit & 0,60 & 0,40 & 0,00 & 0,80 & 0,80 & 0,20 & 0,60 & 0,20 & 0,20 & 0,00 & 0,00 & 0,00 \\
\hline Geloinertinit & 0,60 & 0,40 & 0,00 & 0,80 & 0,80 & 0,20 & 0,60 & 0,20 & 0,20 & 0,00 & 0,00 & 0,00 \\
\hline Total Inertinit & 4,60 & 9,00 & 9,20 & 6,20 & 8,00 & 5,20 & 7,40 & 4,40 & 6,20 & 3,20 & 3,20 & 2,40 \\
\hline Total Maseral & 96,0 & 96,2 & 95,8 & 95,8 & 97,0 & 96,0 & 96,6 & 98,0 & 98,8 & 97,2 & 98,8 & 97,2 \\
\hline \multicolumn{13}{|l|}{ Mineral (vol.\%) } \\
\hline & 1,60 & 1,40 & 1,80 & 1,40 & 0,80 & 1,00 & 1,20 & 0,80 & 0,40 & 1,00 & 0,20 & 0,60 \\
\hline Lempung & 2,20 & 2,00 & 2,40 & 2,20 & 1,40 & 2,00 & 1,60 & 0,80 & 0,80 & 1,20 & 0,60 & 1,60 \\
\hline Mineral lain & 0,20 & 0,40 & 0,00 & 0,60 & 0,80 & 1,00 & 0,60 & 0,40 & 0,00 & 0,60 & 0,40 & 0,60 \\
\hline Total Mineral & 4,00 & 3,80 & 4,20 & 4,20 & 3,00 & 4,00 & 3,40 & 2,00 & 1,20 & 2,80 & 1,20 & 2,80 \\
\hline Total Keseluruhan & 100 & 100 & 100 & 100 & 100 & 100 & 100 & 100 & 100 & 100 & 100 & 100 \\
\hline
\end{tabular}

Berdasarkan komposisi maseral batubara Formasi Muara Enim dengan batubara daerah penelitian menunjukkan komposisi maseral yang tidak jauh berbeda, hanya saja maseral pada batubara daerah penelitian lebih kaya akan kelompok maseral huminit, dibuktikan dengan kandungan kelompok maseral huminit yang lebih tinggi dibandingkan dengan kandungan kelompok maseral huminit yang umum terdapat di Formasi Muara Enim; begitu pula dengan kandungan kelompok maseral liptinit dan inertinit batubara daerah penelitian memiliki nilai kandungan kelompok maseral liptinit dan inertinit yang lebih tinggi dibandingkan dengan yang umumnya terdapat di Formasi Muara Enim.

Kandungan liptinit dan inertinit dalam batubara secara sistematis berhubungan erat dengan kandungan huminit, yakni kandungan liptinit dan inertinit akan berkurang dengan kenaikan kandungan huminit. Kandungan liptinit tidak terkait dengan kandungan inertinit. Demikian pula halnya dengan kandungan mineral, tidak terkait dengan kandungan semua maseral dalam batubara (Santoso, 2015). Fotomikrograf percontoh batubara daerah penelitian dapat dilihat pada Gambar 3 dan 4.

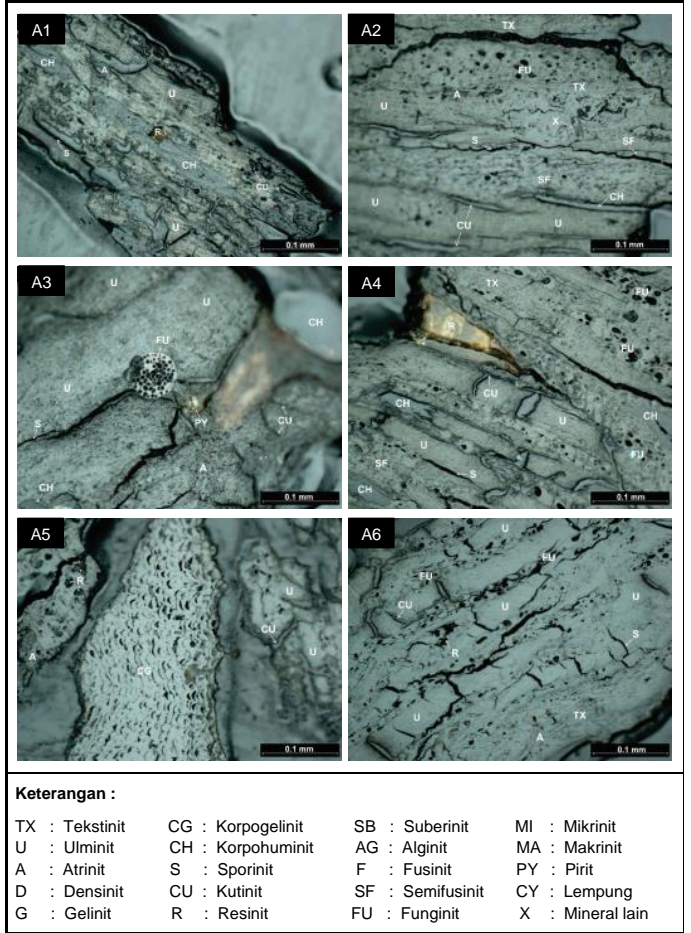

Gambar 3. Fotomikrograf percontoh Lapisan Batubara J dengan perbesaran 20x 


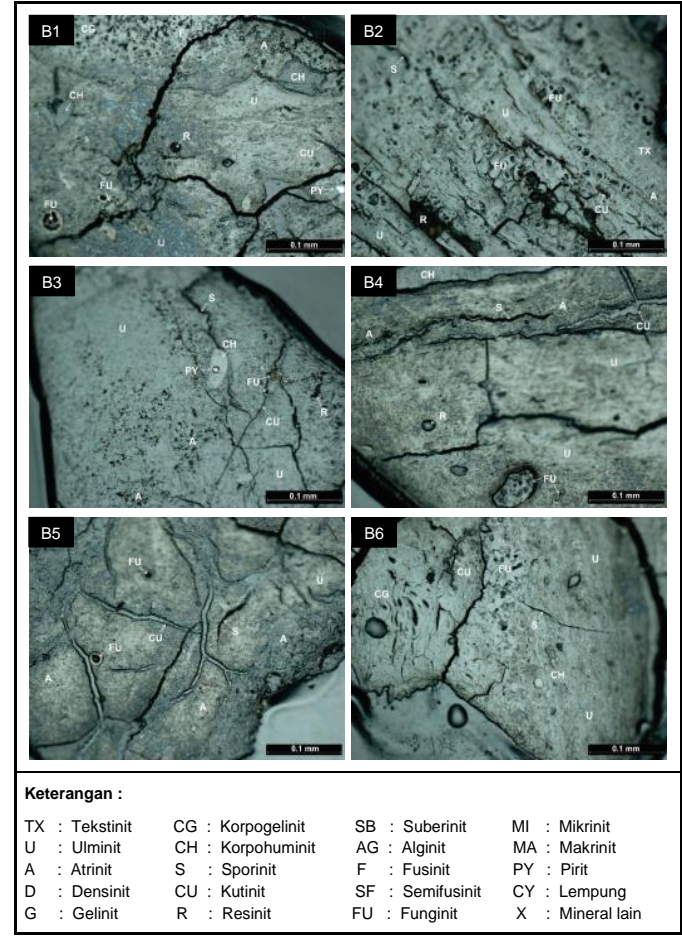

Gambar 4. Fotomikrograf percontoh Lapisan Batubara $\mathrm{K}$ dengan perbesaran 20x

\section{Lingkungan Pengendapan berdasarkan Nilai TPI dan GI}

Batubara pada daerah penelitian memiliki rentang nilai TPI 0,87-1,78 dan GI 7,26-37,33 seperti yang ditunjukkan pada Tabel 3 .

Tabel 3. Nilai TPI dan GI

\begin{tabular}{ccccc}
\hline No & $\begin{array}{c}\text { Lapisan } \\
\text { Batubara }\end{array}$ & $\begin{array}{c}\text { Kode } \\
\text { Percontoh }\end{array}$ & $\begin{array}{c}\text { Nilai } \\
\text { TPl }\end{array}$ & Nilai Gl \\
\hline 1 & & A1 & 1,16 & 19,70 \\
2 & & A2 & 1,65 & 7,70 \\
3 & & A3 & 1,78 & 7,26 \\
4 & J & A4 & 0,88 & 14,63 \\
5 & & A5 & 1,72 & 9,14 \\
6 & & A6 & 1,39 & 15,48 \\
\hline 7 & & B1 & 1,53 & 11,26 \\
8 & & B2 & 0,91 & 20,00 \\
9 & \multirow{2}{*}{ K } & B3 & 1,27 & 13,50 \\
10 & & B4 & 0,87 & 26,69 \\
11 & & B5 & 1,08 & 27,75 \\
12 & & B6 & 1,27 & 37,33 \\
\hline
\end{tabular}

Nilai TPI pada daerah penelitian didominasi oleh nilai TPI $>1$ (percontoh A1, A2 A3, A5, A6, B1, B3, B5 dan B6). Hal ini mengindikasikan tipe vegetasi yang dominan adalah tumbuhan berkayu dengan tingkat pengawetan jaringan yang baik dicirikan dengan tingginya kandungan grup maseral humotelinit. Kondisi ini mencerminkan adanya penebalan gambut secara cepat dengan kondisi basah dan lembab, sehingga mendukung tingkat pengawetan jaringan tumbuh secara baik. Tingkat pengawetan jaringan sel tumbuhan yang baik ini diperkirakan berhubungan dengan lingkungan pengendapan gambut yang selalu dalam kondisi basah dan $\mathrm{pH}$ yang rendah (Calder, Gibling and Mukhopadhyay, 1991; Diessel, 1992). Untuk nilai TPI $<1$ (percontoh A4, B2 dan B4) menunjukkan tumbuhan penyusunnya tumbuhan perdu.

Nilai GI pada daerah penelitian memiliki nilai sedang, sehingga secara umum kondisi lingkungan gambut berada pada kondisi basah atau terjaga kelembabannya. Terdapat anomali pada percontoh A2, A3 dan A5 yang memiliki nilai $\mathrm{Gl}$ yang cukup rendah $(<10)$. Hal ini terjadi akibat adanya peningkatan nilai grup maseral teloinertinit. Implikasi rendahnya nilai Gl mengindikasikan proses penggambutan mengalami oksidasi yang lebih intensif atau gambut terendapkan pada kondisi langsung dengan udara atau oksigen (kering). Selanjutnya, nilai TPI dan GI tersebut diplot dalam diagram TPI-GI menurut Diessel (1986) seperti yang ditunjukkan pada Gambar 5 .

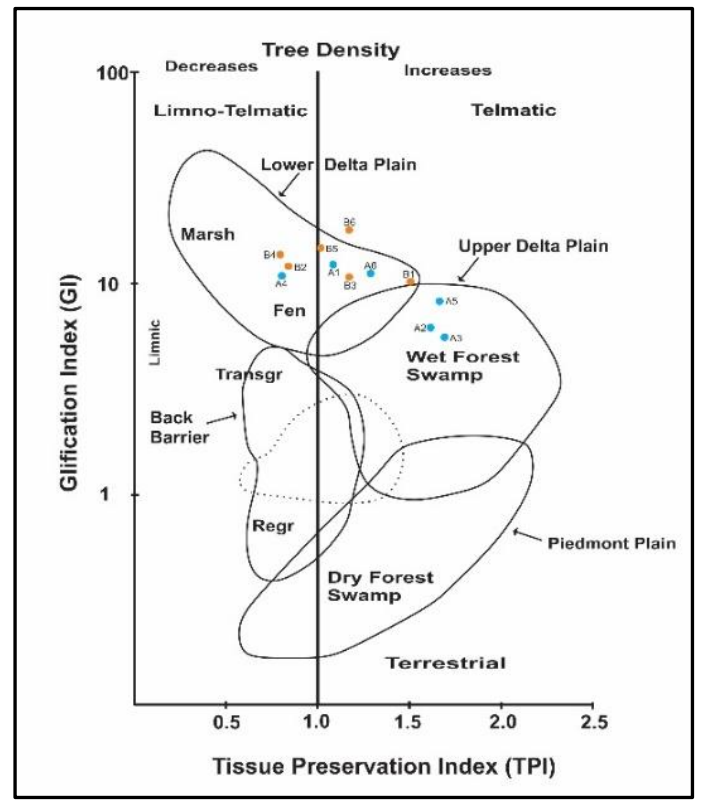

Gambar 5. Diagram TPI dan GI Batubara Daerah Penelitian (Diessel, 1986). 
Hasil pengeplotan pada diagram TPI-GI (Gambar 5) menunjukkan bahwa batubara pada daerah penelitian terendapkan di antara rawa gambut wet forest swamp dan rawa gambut fen dan di antara kondisi lingkungan telmatik dan kondisi lingkungan limnotelmatic.

Wet forest swamp merupakan rawa gambut yang selalu basah saat musim kemarau hingga musim dingin, proses pengendapan batubara berada pada rawa gambut yang relatif lembab atau basah atau selalu tergenang oleh air dengan kata lain pembentukan batubara berkembang dengan baik. Tumbuhan pengisi gambut didominasi oleh tumbuhan kayu, dicirikan dengan kandungan kelompok maseral huminit yang tinggi (Teichmüller, 1989). Sedangkan fen merupakan rawa gambut yang kaya akan tumbuhan perdu dan beberapa jenis pohon lainnya.

Lingkungan telmatik merupakan lahan yang mengalami kondisi terus-menerus digenangi baik oleh air tawar maupun air laut. Sifat lingkungan ini yaitu eutrofik sampai dengan mesotrofik dan didominasi tumbuhan berkayu. Kondisi lingkungan telmatik akan menghasilkan lahan gambut yang tidak terganggu dan tumbuh in-situ serta tingkat kerapatan pepohonan bertambah, ditunjukkan dengan nilai TPI dan GI yang relatif cukup tinggi. Hal ini didukung dengan kandungan subkelompok maseral humotelinit yang tinggi (Diessel, 1992). Sementara itu, lingkungan limno-telmatic merupakan kondisi lahan yang selalu digenangi air, baik saat musim pasang surut ataupun dalam kondisi biasa. Sifat lingkungan ini berupa mesotrofik mengandung percampuran antara air laut dengan air tawar, didominasi oleh tumbuhan perdu diikuti tumbuhan kayu.

Berdasarkan hasil analisis lingkungan pengendapan menggunakan konsep Diessel (Diessel, 1986) didapatkan bahwa batubara daerah penelitian terendapkan di antara lingkungan pengendapan lower delta plain dan upper delta plain (Gambar 5). Dengan demikian, apabila ditinjau berdasarkan konsep model lingkungan pengendapan menurut Horne $d k k$. (1978), batubara daerah penelitian tersebut dapat dikatakan terendapkan pada lingkungan pengendapan transitional lower delta plain.
Menurut Horne $d k k$. (1978), lingkungan pengendapan transitional lower delta plain merupakan transisi lingkungan upper delta plain dengan lingkungan lower delta plain. Endapan sedimen terdiri atas perpaduan antara lingkungan lower delta plain dan upper delta plain yaitu perselingan batulanau, batulempung dan batupasir seperti yang terlihat pada kolom stratigrafi daerah penelitian (Gambar 6). Batubara daerah ini memiliki ciri lapisan batubara relatif tebal, seperti yang ditunjukkan oleh batubara daerah penelitian yang memiliki kisaran ketebalan 0,10-27,50 meter, dengan rata-rata ketebalan $\pm 9,26$ meter dan kandungan sulfur rendah. Lapisan batubara tersebar meluas dengan kecenderungan sedikit memanjang, sejajar jurus pengendapan dikarenakan perkembangan rawa yang ekstensif. Splitting juga berkembang pada lingkungan pengendapan ini, dibuktikan dengan terdapatnya sisipan lapisan batuan pada batubara dengan ketebalan berkisar 0,12-0,38 meter. Sisipan tersebut terdiri atas carbonaceous mudstone, boundstone, dan mudstone (Gambar 6). Pengendapan terpengaruh oleh transgresi air laut, namun tidak terlalu signifikan dibuktikan dengan rendahnya kandungan mineral pirit $(0,20-1,80 \%)$.

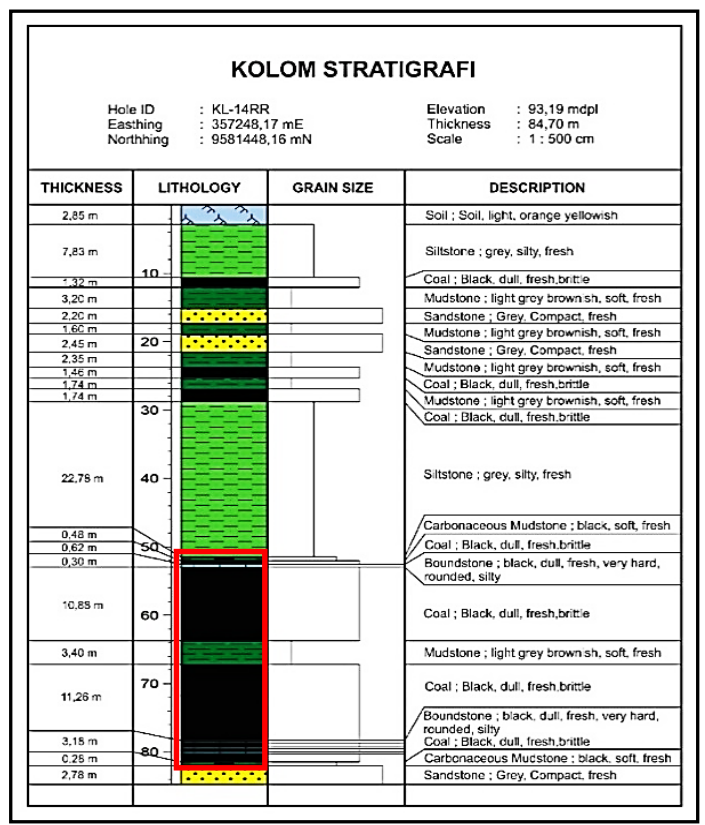

Gambar 6. Kolom stratigrafi daerah penelitian 


\section{Lingkungan Pengendapan berdasarkan Analisis Stratigrafi}

Untuk memperkuat gagasan mengenai penentuan lingkungan pengendapan batubara, dilakukan pula analisis stratigrafi (litofasies). Interpretasi lingkungan pengendapan berdasarkan analisis stratigrafi dilakukan dengan membandingkan fasies-fasies batuan yang telah dibuat dengan fasies model yang telah ada sebelumnya, sehingga didapatkan hasil berupa pola pengendapan (Pratama and Amijaya, 2015).

Daerah penelitian merupakan daerah pengendapan delta, ketika sebuah sungai memasuki laut dan terjadi penurunan kecepatan secara drastis, yang diakibatkan bertemunya arus sungai dengan gelombang, endapan-endapan yang dibawanya akan terendapkan secara cepat dan terbentuklah sebuah delta. Oleh karena itu, model pembanding yang digunakan adalah konsep model lingkungan pengendapan daerah delta menurut Horne $d k k$. (1978).

Selain itu, penentuan lingkungan pengendapan ini didukung pula dengan succession vertical delta (litologi suatu delta secara vertikal) (Gambar 7). Diketahui bahwa pada lingkungan pengendapan delta memiliki susunan litologi secara umum berupa batulempung, batupasir, batulanau, dan batubara. Susunan litologi tersebut didasarkan pada ukuran butirnya, sehingga pada lingkungan pengendapan delta ini litologinya akan berdasarkan pada ukuran butir dari yang semakin besar sampai ke ukuran butir paling kecil (Fauziah, 2020).

Berdasarkan analisis profil menggunakan model pendekatan yang dikemukakan oleh Horne $d k k$. (1978), diketahui bahwa lapisan batubara diendapkan pada lingkungan rawa (Gambar 8), karena adanya kontak roof dan floor yang memperlihatkan kandungan karbonan berangsur terdiri atas batubara menjadi batulempung karbonan yang kaya kandungan unsur organik berupa unsur karbon. Kandungan unsur karbon ini diperlihatkan oleh warna litologi hitam. Dari kandungan unsur organik tersebut, pembentukan batubara berlangsung dalam kondisi tenang, sehingga ditafsirkan diendapkan pada lingkungan rawa (Islamy, 2016).

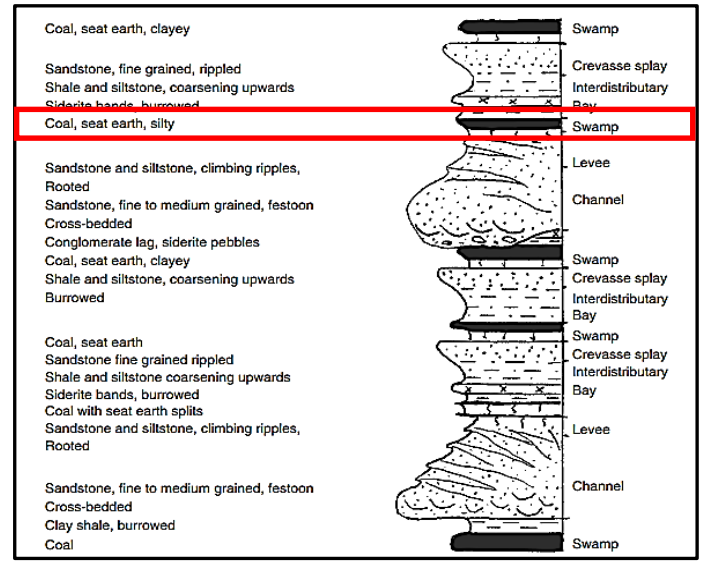

Gambar 7. Sekuen Vertikal Transitional Lower Delta Plain (Horne $d k k ., 1978$ )

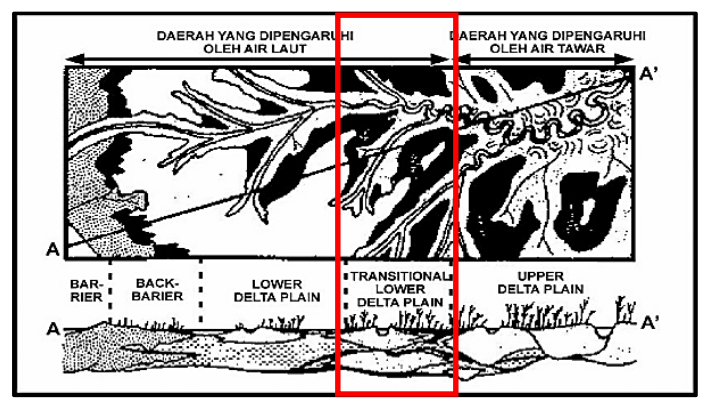

Gambar 8. Model lingkungan pengendapan batubara pada daerah penelitian (Horne $d k k$, 1978).

\section{KESIMPULAN DAN SARAN}

\section{Kesimpulan}

Hasil analisis petrografi organik batubara daerah penelitian menunjukkan kandungan nilai TPI dan GI yang sedang, sehingga dapat diinterpretasi dengan diagram Diessel (Diessel, 1986) yang menunjukkan bahwa batubara tersebut diendapkan pada lingkungan pengendapan lower delta plain hingga upper delta plain dengan sublingkungan pengendapannya berupa telmatik dan limnotelmatic pada rawa gambut wet forest swamp dan fen. Bila ditinjau berdasarkan klasifikasi model lingkungan pengendapan batubara daerah penelitian masuk dalam lingkungan pengendapan transitional lower delta plain. Didukung pula oleh data hasil analisis stratigrafi, yang menyatakan bahwa lapisan batubara daerah penelitian diendapkan pada lingkungan rawa delta, dicirikan dengan 
adanya kontak atas dan bawah lapisan memperlihatkan kandungan karbonan yang berangsur terdiri atas batubara menjadi batulempung karbonan.

\section{Saran}

Untuk mengetahui secara detail karakteristik batubara daerah penelitian, perlu dilakukan penambahan dan peluasan lokasi pemercontohan. Pemercontohan ini perlu dilakukan secara representatif, baik percontoh di permukaan maupun percontoh hasil kegiatan pengeboran.

\section{UCAPAN TERIMA KASIH}

Penulis mengucapkan terima kasih kepada Kepala Pusat Penelitian dan Pengembangan Geologi Kelautan (PPPGL) yang telah memberikan izin menggunakan fasilitas laboratorium geologi untuk menunjang penelitian ini.

\section{DAFTAR PUSTAKA}

Bishop, M. G. (2001) South Sumatra Basin Province, Indonesia: The Lahat/Talang Akar-cenozoic total petroleum system. Colorado: USGS.

Calder, J. H., Gibling, M. R. and Mukhopadhyay, P. K. (1991) "Peat formation in a Westphalian B Piedmont setting, Cumberland Basin, Nova Scotia: Implications for the maceral-based interpretation of rheotrophic and raised paleomires," Bulletin de la Société Géologique de France, 162(2), pp. 283-298.

Diessel, C. F. K. (1986) "On the correlation between coal facies and depositional environments," in. New South Wales: Proceedings of the 20th Symposium on Advances in the Study of the Sydney Basin, Department of Geology, University of Newcastle, pp. 19-22.

Diessel, C. F. K. (1992) Coal-Bearing Depositional Systems, Coal-Bearing Depositional Systems. doi: 10.1007/978-3-642-75668-9.

Fauziah (2020) Peranan Lingkungan Pengendapan Batubara Terhadap Kualitas Batubara di PT Bhadra Pinggala Sejahtera Desa Separi, Kecamatan Tenggarong Seberang, Kabupaten Kutai Kartanegara Provinsi Kalimantan Timur. Universitas Islam Bandung.
Gafoer, S., Cobrie, T. and Purnomo, J. (1986) "Peta geologi lembar Lahat (1012), Sumatera Selatan, scale 1:250.000." Bandung: Pusat Survey Geologi, p. 1.

Horne, J. C., Ferm, J. C., Caruccio, F. T. and Baganz, B. P. (1978) "Depositional Models in Coal Exploration and Mine Planning in Appalachian Region," AAPG Bull, 62(12), pp. 2379-2411. doi: $\quad$ 10.1306/c1ea5512-16c9-11d78645000102c1865d.

IAGI Learning Centre (2017) Identifikasi Karakteristik Batuan Yang Berpotensi Sebagai Batuan Reservoir Pada Daerah Baturaja Dan Bangka Utara (Part I), Ikatan Ahli Geologi Indonesia (IAGI).

ICCP (1971) International Handbook of Coal Petrology, 1st Supplement to 2nd Edition, International handbook of coal petrography: Supplement to the 2nd edition. Paris: Centre National de la Recherche Scientifique.

Islamy, F. (2016) Geologi dan Pola Sebaran serta Kemenerusan Lapisan Batubara Daerah Gunung Megang, Kecamatan Gunung Megang, Kabupaten Muara Enim, Provinsi Sumatera Selatan. Universitas Pembangunan Nasional "Veteran."

Mijnbouw, S. (1978) Explanatory notes to The geological map of the South Sumatra Coal Province. Jakarta (unpublished).

Pratama, D. A. P. and Amijaya, D. H. (2015) "Lingkungan pengendapan batubara formasi warukin berdasarkan analisis petrografi organik di daerah Paringin, cekungan Barito, Kalimantan Selatan," in Proceeding Seminar Ke-8 Akademia-Industry Linkage. Universitas Gadjah Mada, pp. 582-593.

Purnama, A. B., Salinita, S., Sudirman, S., Sendjaja, Y. A. and Muljana, B. (2018) "Penentuan lingkungan pengendapan lapisan batubara D, Formasi Muara Enim, Blok Suban Burung, Cekungan Sumatera Selatan," Jurnal Teknologi Mineral dan Batubara, 14(1), pp. 1-18. doi: 10.30556/jtmb.Vol14.No1.2018.182.

Santoso, B. (2015) Petrologi batubara Sumatra dan Kalimantan: jenis, peringkat, dan aplikasi. Jakarta: LIPI Press.

Stach, E., Mackowsky, M.-T., Teichmüller, M., Taylor, G. H., Chandra, D. and Teichmüller, R. (1982) Stach's textbook of coal petrology, Book. 
Kajian Lingkungan Pengendapan Batubara Berdasarkan Analisis Petrografi Organik ... Amelia Puspa Monita dkk.

Susilawati, R. and Ward, C. R. (2006) "Metamorphism of mineral matter in coal from the Bukit Asam deposit, south Sumatra, Indonesia," International Journal of Coal Geology, 68(3-4), pp. 171-195. doi: 10.1016/j.coal.2006.02.003.
Teichmüller, M. (1989) "The genesis of coal from the viewpoint of coal petrology," International Journal of Coal Geology, 12(1-4), pp. 1-87. doi: 10.1016/0166-5162(89)90047-5. 
